Ann. Génét. Sél. anim., 1976, 8 (2), 265-271.

\title{
EXPERIMENTAL RESULTS \\ ON CROSSBREEDING INVOLVING BEEF (PIEDMONT AND ROMAGNA) AND DAIRY CATTLE (FRIESIAN) IN ITALY (1)
}

\author{
P. SANTORO
}

\author{
Istituto di Zootecnia e Nutrizione Animale, \\ Facoltà di Medicina Veterinaria, \\ Università degli Studi, \\ Via S. Giacomo, 11, \\ 40126 Bologna, Italia
}

\section{SUMMARY}

Two trials have been carried out in order to evaluate the ability for beef production of " Double-muscled "Piedmont $\times$ Friesian and Romagna $\times$ Friesian crosses, males and females. Compared with Friesian purebred young bulls, the $F_{1}$ male offsprings from both crossings showed higher level performances for all the traits considered. Female crosses exhibited good carcass traits. On the whole, Friesian purebred young bulls gave the lowest performances. The $P \times F$ female crosses produced higher dressing percentages than the $R \times F$ females. In conclusion, although female crosses appear to possess a good ability for beef production, a three-breed crossing programme - exploiting $\mathrm{F}_{1}$ heifers to obtain more productive $\mathrm{F}_{2}$ crosses - would be, however, preferable.

\section{INTRODUCTION}

The results here presented are part of a larger experimental project currently in progress at our Institute with the purpose of finding out the possibilities of improving beef production in cattle by exploiting two-breed crosses. The present study will report some data collected in two different experimental trials, carried out on two $F_{1}$ progenies, males and females, from different crosses. In the first experiment, the performance traits, relating to quality and quantity of beef production in young

(1) Communication presented at 26th Annual Meeting of European Association for Animal Production.

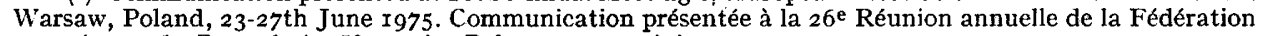
européenne de Zootechnie. Varsovie, Pologne, 23-27 juin 1975. 
bulls and heifers resulting from crossing "Double-muscled " Piedmont $\times$ Italian Friesian $(P \times F)$ breeds, were investigated. In the second experiment, a research was carried out on $\mathrm{F}_{1}$ crosses between Romagna and Italian Friesian $(R \times F)$ breeds.

\section{MATERIALS AND METHODS}

The animals used in the first experiment were 2 I male Piedmont $\times$ Friesian crosses $(P \times F$ $\left.\sigma^{*} \sigma^{*}\right)$, ro females from the same crossing $(P \times F+q)$ and 2 I male Friesian purebred calves $\left(F \delta^{*} \delta^{*}\right)$. All the crossbreds dropped in the same research farm were used in this experiment ; the straightbred Friesians, on the contrary, were chosen at random from those born in the same period. In crossbreds, the double muscled condition resulted to be latent at birth and appeared later in development. It occurred, however, in the affected calves, with a varying intensity. This condition was never found very marked and appeared clearer in males.

The animals were raised in open shelters and loose housed in separate lots. The experiment started with the beginning of the post-weaning period, when the calves were 80 to 85 days old. The pre-weaning period acted as a pre-experimental test. Diets included hay over the first few months and afterwards corn silage. Throughout the whole experimental period also concentrates were added, as usually practiced. Owing to the fact that the animals were loose housed, feed intake and feed conversion were measured on average within each group. Hence, no statistical and mathematical analysis has been made out of these data. Once the animals had reached a sufficient finishing degree, they were slaughtered. After a 24 hrs pre-refrigeration period, thirty right sides were selected at random (Io from each group) and stored in a freezer for 6 days. After this time, the right sides were submitted to dissection and complete separation tests (muscle, fat and bone).

In a subsequent experiment the animals used were ro male $\mathrm{F}_{1}$ calves from Romagna $\times$ Friesian cross $\left(R \times F \delta^{\dagger}\right)$, ro females from the same crossing $(R \times F$ o purebred calves $\left(F \delta^{*} \delta^{*}\right.$. This second trial was conducted in a different experimental farm where the animals were conventionally reared in barns and kept individually tied. In this manner it was possible to determine food intake and feed utilization for each animal. All the animals were chosen at random in the same farm among those born in a month period.

Also this experiment started when the calves were on average 79 to 85 days old and concerned the post-weaning period. Diets included a small quantity of hay and concentrates according to live-weights. As the animals appeared to have attained a good finishing degree, they were slaughtered. After a preliminary refrigeration of $24 \mathrm{hrs}$, the cold carcasses were weighed and all the right sides stored in a freezer for 6 days. After this period, these sides were submitted to dissection and complete separation, in order to evaluate the major wholesale cuts and separable components.

\section{RESULTS}

\section{A. - First experiment (Piedmont $\times$ Friesian)}

The results from the first experiment are given in table $I$. In the comparison between Piedmont $\times$ Friesian crossbred males and females ( $\mathrm{I}$ vs 2 ), the formers present a significantly higher daily gain and a slightly better feed conversion rate. Crossbred females, however, are sufficiently finished for slaughter in a shorter time, though at much lower weights. Slaughtering tests show significant advantages in favour of crossbred males, since they are superior to females with respect to dressing percentage, although this difference does not reach significance. This appears to be due mainly to the greater weight of viscera in females $(P<0.01)$. Complete separation and dissection tests on the right sides, too, show crossbred males to have, on the whole, better carcasses than females, in that they present right sides much heavier and richer in percentage of lean $(\mathrm{P}<0.05)$; females, on the contrary, produce fatter carcasses $(P<0.0 I)$, but relatively more developed hindquarters, which yield higher quality cuts. 
TABLE I

Data obtained in the first experiment (Piedmont $\times$ Friesian) Principaux résultats concernant la première expérience (Piémontaise $\times$ Frisonne)

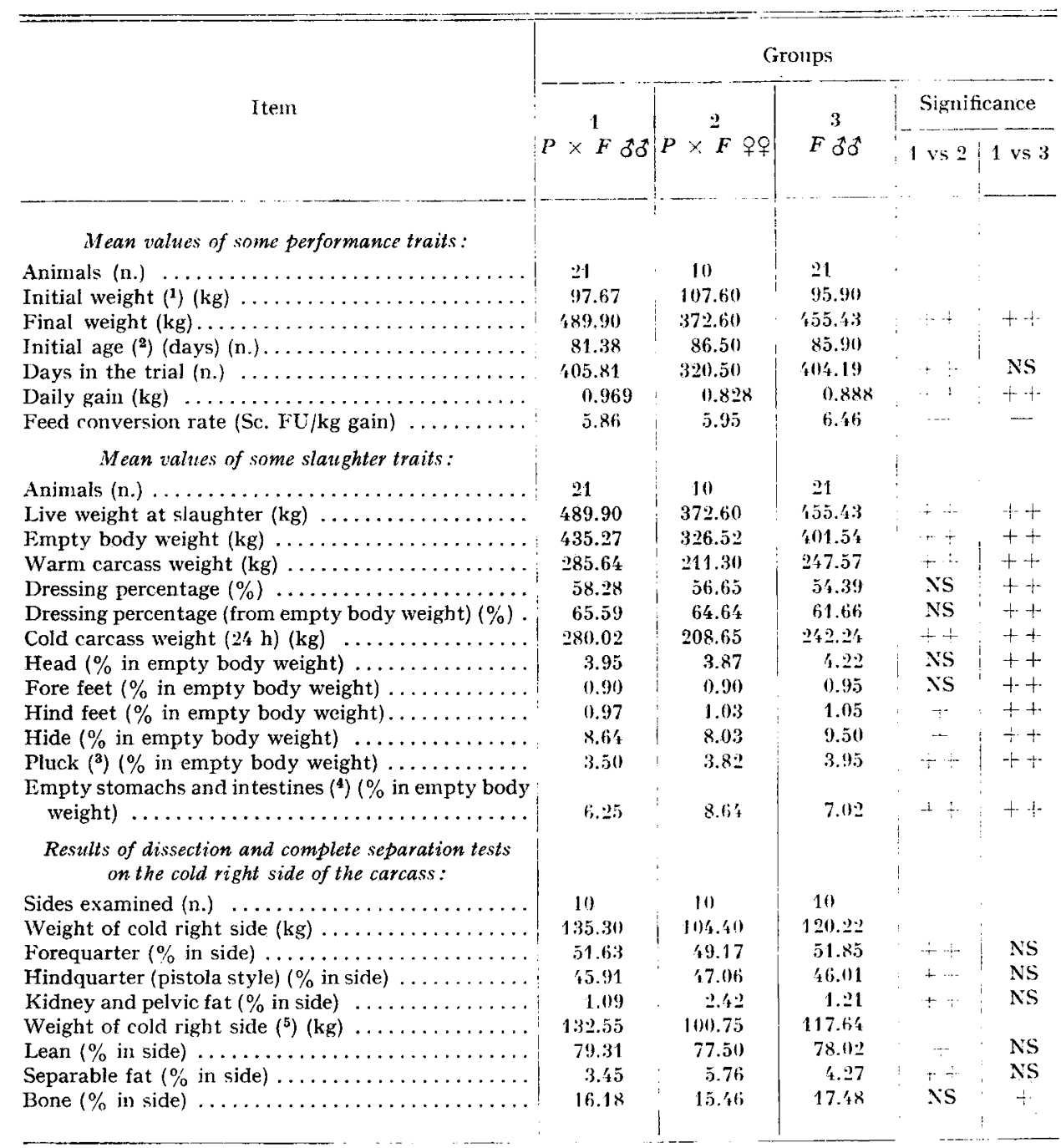

(1) Weaning weight.

(2) Weaning age.

$\left({ }^{3}\right)$ Including heart, lungs, trachea, cesophagus, liver and spleen.

$\left({ }^{4}\right)$ In females is also included a small part of genital apparatus.

$\left({ }^{5}\right)$ Kidney, kidney fat, pelvic fat and tail are not included in this weight.

NS Not significant.

+ Significant difference with $P<0.05$.

++ Significant difference with $\mathrm{P}<0.01$. 
TABLE 2

Data obtained in the second experiment (Romagna $\times$ Friesian) Principaux résultats concernant la deuxième expérience (Romagnole $\times$ Frisonne)

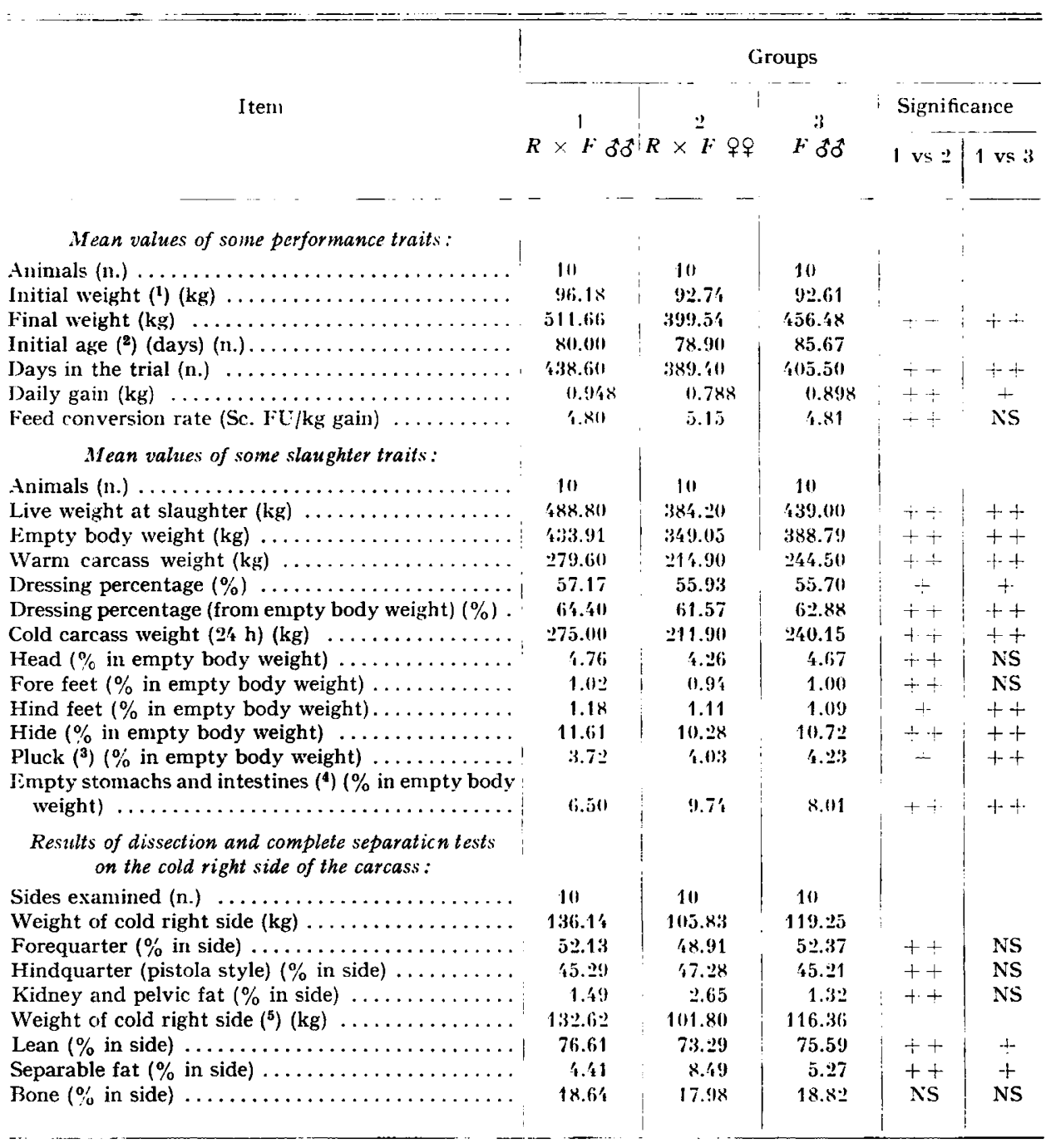

(1) Weaning weight.

$\left({ }^{2}\right)$ Weaning age.

( ${ }^{3}$ Including heart, lungs, trachea, œsophagus, liver and spleen.

(4) In females is also included a small part of genital apparatus.

$\left({ }^{5}\right)$ Kidney, kidney fat, pelvic fat and tail are not included in this weight.

NS Not significant.

+ Significant difference with $\mathrm{P}<0.05$.

++ Significant difference with $\mathrm{P}<0.01$. 
From the comparison between crossbred and straightbred males (I vs 3), it turns out that crossbreeding has allowed to improve beef production at all levels. Crossbreds, in fact, are found to have higher daily gains than pure Friesians $(\mathrm{P}<0 . \mathrm{or})$ and more favourable feed conversion rates. Furthermore, crossbreds reach a finishing degree for slaughtering at much heavier weights, though in the same period of time as pure Friesians, and, consequently, they have heavier carcasses $(\mathrm{P}<0.0 \mathrm{I}) . P \times F$ offsprings give significantly higher dressing percentages ; head, feet, hide, pluck, stomachs and intestines are, in fact, heavier in purebred Friesians. All these differences are highly significant $(\mathrm{P}<0.0 \mathrm{I})$. As concerns complete separation tests on the right sides, $P \times F$ produce higher quality carcasses than pure Friesians. As a matter of fact, crossbred right sides appear to have a higher percentage of lean, a lower percentage of fat and a smaller incidence of bone. Only this latter difference, however, exceeds the minimum value of statistical significance.

\section{B. - Second experiment (Romagna $\times$ Friesian)}

The results of the second experiment are shown in table 2. From the comparison between $R \times F$ males and females (I vs 2), the formers show a greater ability for beef production, in that they are superior in growth and feed conversion rate. Females appear to be finished for slaughter in a shorter time, but at much lower weights. All these differences are highly significant $(\mathrm{P}<0.0 \mathrm{I})$. Male crossbreds are superior in dressing percentage to females. Head, feet, and hide are heavier in males, whereas viscera in females. The different levels of significance are reported in table.

Males exhibit the best carcasses, in that, besides being far heavier, they yield a higher percentage of lean and a lower percentage of fat $(P<0.0 I)$. Females, however, show a lower incidence of bone, although this difference does not reach significance. On the other hand, even if crossbred female carcasses are much lower in weight, they present proportionally more developed hindquarters, which yield higher quality cuts. In this experiment too, females result to have a larger amount of kidney fat $(\mathrm{P}<0.0 \mathrm{r})$.

By comparing $R \times F$ male offsprings with straightbred male Friesians (I vs 3), it turns out that the two-breed crossing has improved beef production at all levels, even though not so remarkably as in the first experiment. Male crosses, in fact, are found to be superior in daily gains to pure Friesians $(P<0.05)$, but to have a rather identical feed conversion. Furthermore, crossbreds are significantly superior in dressing percentage ; head, feet and hide are heavier in $\mathrm{F}_{1}$ offsprings, viscera in purebred Friesians $(\mathrm{P}<\mathrm{o} .0 \mathrm{I})$. Dissection tests do not reveal any significant differences, whereas the composition of the right side shows that the use of the Romagna breed has allowed to increase the contents of lean of the carcass $(P<0.05)$, with a consequent decrease in fat percentage.

\section{DISCUSSION}

The results obtained show that "Double-muscled" Piedmont $\times$ Friesian and Romagna $\times$ Friesian crosses, both males and females, possess a high degree of specialization for beef production. $F_{1}$ male offsprings, however, in both experiments; 
provided higher performances than $F_{1}$ females, in that they were superior in daily gain, feed conversion and dressing percent. Moreover, they produced higher quality carcasses, $i$. $e$. with a greater lean content. Crossbred females, though slaughtered after a shorter growth and fattening period, presented much lighter and excessively fat carcasses.

In $P \times F$ offsprings, the total feed consumed - expressed in Sc. FU - necessary to produce I $\mathrm{kg}$ of lean was found to be of 10.7 for males and I0.2 for females. In $R \times F$ offsprings the same relation was 9.8 for males and 10.5 for females.

From the comparison between crossbred and straightbred Friesian males, it turns out that two-breed crossing has improved the ability for beef production of pure Friesians. The $P \times F$ crossing has increased daily gain, and remarkably improved feed conversion. An improving effect, but not so remarkable, has been detected for the $R \times F$ crossing, where we have a superior daily gain, but the same feed conversion rate as pure Friesians. Crossbred males from both trials exhibited heavier carcasses and higher dressing percentages.

The crossbreds in the second experiment showed lower dressing percentages than the crossbreds used in the first experiment, and this appears to be caused by the higher weights of head, feet and especially hide in Romagna cattle, compared with Piedmont cattle. Similar findings were reported by another Author (Bonsembiante, I974) from trials in which crossbreds of the same crosses were involved.

The $P \times F$ crossing, contrary to all expectations, has not so largely improved carcass quality. All the same, crossbred males present a higher proportion of lean and a lower proportion of fat in the right side with respect to straightbred Friesians, even though these differences do not reach significance. $P \times F$ offsprings, in addition, have a lower incidence of bone and this difference do reach significance $(\mathrm{P}<0.05)$.

Also the $R \times F$ crossing has improved carcass quality, in that the higher percentage of lean and the lower percentage of fat result significant $(P<0.05)$.

In both trials, the relation between total feed consumed - expressed in Sc. FU - and lean obtained (Sc. FU/kg lean) is found to be more favourable in crossbred males than in Friesian males (I0.7 vs 12.5 in the first experiment; 9.8 vs 9.95 in the second). These data indirectly confirm the results from the Sc. FU/kg gain ratio.

The data obtained point out that "Double-muscled" Piedmont $\times$ Friesian and Romagna $\times$ Friesian male crosses are highly specialized for beef production. A higher carcass quality could have been expected from $P \times F$ males, but probably they had not the appropriate rate of maturity for slaughter. These findings, however, are in agreement with those referred in our previous study (SANTORO, ZAGHINI and QUARANTINI, I973).

Crossbred females too, show on the whole a good specialization degree for beef production. Even if they did not provide so high performances as crossbred males, $\mathrm{F}_{1}$ females, however, did not result inferior to Friesian males in some of the traits considered. Although female crosses resulted to possess a good ability for beef production, we consider, however, that they could be used with greater profit for threebreed crossings. In our opinion, in fact, $F_{1}$ heifers should rather be mated to a sire of a third different breed, highly specialized in beef production, so as to obtain even more productive $\mathrm{F}_{2}$ crosses. In this view, the Romagna breed, though not so highly specialized as the Piedmont, being provided with a high rusticity degree and a good 
grazing capacity - as we reported in previous studies (MONETTI and SANTORO, I972 ; FALASCHINI et al., I974) - could be profitably used in crossbreeding.

Reçu pour publication en avril $19 \pi 6$.

\title{
RÉSUMÉ
}

\author{
RÉSULTATS EXPÉRIMENTAUX SUR LE CROISEMENT \\ ENTRE RACES BOVINES A VIANDE (PIÉMONTAISE, ROMAGNOLE) \\ ET RACE A LAIT (FRISONNE) EN ITALIE
}

Deux essais ont été effectués visant à évaluer l'aptitude à la production de viande chez des métis Piémontais de la cuisse ("culard") $\times$ Frisonne et Romagnole $\times$ Frisonne, mâles et femelles. Par rapport aux Frisons mâles de race pure, les $F_{1}$ mâles des deux croisements ont donné des résultats meilleurs et de loin pour tous les caractères considérés. Les femelles des deux croisements différents ont montré des carcasses plus grasses que les mâles. Les mâles de la race Frisonne ont offert dans l'ensemble les plus mauvais résultats. Les femelles $P \times F$ ont donné de meilleurs rendements à l'abattage que les femelles $R \times F$. Malgré une bonne aptitude à la production de viande présentée en définitive par les femelles, un programme de croisement de trois races avec utilisation de génisses $F_{1}$ pour la production des croisements $F_{2}$ encore plus productifs est toutefois jugé préférable.

\section{RIASSUNTO}

\author{
ALCUNI RISULTATI SPERIMENTALI SULL'INCROCIO INDUSTRIALE \\ NELLA PRODUZIONE DELLA CARNE BOVINA IN ITALIA : \\ PIEMONTESE $\times$ FRISONA E ROMAGNOLA $\times$ FRISONA
}

Sono state effettuate due prove al fine di valutare l'attitudine alla produzione della carne in meticci Piemontese "della coscia" $\times$ Frisona e Romagnola $\times$ Frisona, maschi e femmine. A confronto dei Frisoni maschi di razza pura, i maschi $F_{1}$ provenienti dai due diversi incroci hanno dato risultati di gran lunga migliori per tutti i caratteri considerati. Le femmine meticce hanno offerto alcune buone caratteristiche delle carcasse. I maschi di razza Frisona hanno fatto regisstrare, nel complesso, i peggiori risultati. Le femmine $P \times F$ hanno dato migliori rese di macellazione delle femmine $R \times F$. Anche se le femmine hanno presentato, in definitiva, una buona attitudine per la produzione della carne, si ritiene che un programma d'incrocio a tre razze impiegando le manze $F_{1}$ per produrre meticci $F_{2}$ - sia comunque preferibile.

\section{REFERENCES}

Bonsembiante M., r974. Risultati sperimentali dell'incrocio tra bovini delle razze da carne e da latte. Assalzoo, notiziario $n$. 19, 66 Riunione del 17 ottobre 1974 , Milano.

Falaschini A., Santoro P., Falaschini A. F., Parisini P., 1974. Origini, evoluzione ed avvenire della razza bovina Romagnola. Edagricole, Bologna.

Monetti P. G., Santoro P., I972. La produzione del vitellone con soggetti provenienti o meno dal pascolo. Riv. Zoot. Agric. Vet., 10, 3-18.

Santoro P., Zaghini G., Quarantini D., r973. Esperienze sull'incrocio industriale Piemontese $\times$ Frisona : rilievi alla macellazione e caratteristiche delle carcasse di vitelloni maschi e femmine. Atti Soc. It. Sci. Vet., 27, 473-477. 